\title{
Strategy of Water Resource Utilization in Upper Narmada Basin
}

\author{
R.N. Shrivastava*, R.K. Nema and M.K. Awasthi \\ Department of Soil and Water Engineering, College of Agriculture Engineering, J.N.K.V.V. \\ Jabalpur (MP) 482004, India \\ *Corresponding author
}

\begin{tabular}{|l|}
\hline Ke y w o r d s \\
Water resource \\
utilization, \\
Narmada basin \\
\hline Article Info \\
\hline $\begin{array}{l}\text { Accepted: } \\
\text { 07 April } 2018 \\
\text { Available Online: } \\
\text { 10 May } 2018\end{array}$ \\
\hline
\end{tabular}

\section{A B S T R A C T}

The present study was conducted to find status of water resource use and strategies for its future. The study was conducted in the five revenue districts of upper Narmada basin. In order to assess the status of water resource utilization in UNB first of all net ground water availability was computed, using annual recharge values. Methodology supported and recommended by G.E.C. (1997) was followed. Revenue blocks were taken as unit for assessment. To estimate the ground water recharge water level fluctuation method was used. So obtained annual ground water recharge was used to arrive at ground water potential using the existing ground water withdrawal. A strategy is proposed for the development of potential available as, it should be developed up to seventy percent only to keep the block in safe category as per the criteria. Keeping this strategy in view, utilizable ground water potential was assessed. The proposed ground water development for future irrigation was obtained in a phased manner through construction of different types of ground water structures. This number of feasible ground water structures was decided as per the hydro-geological situations. Further the additional area which can be brought under irrigation with these additional wells has also been computed as per the GEC norms. Separate planning for utilizable water resource of each district has been made. Thus, the present status of water resources utilization in UNB has been determined and planning for its future development is made. Suiting to this, crop plan for each district has made. After the assessment of ground water potential and stage of ground water development areas having ground water development more than 65 per cent are considered as stressed areas. These areas need artificial recharge today and in future also.

\section{Introduction}

Water resource management and planning should be seen in a context of food grain availability. India has sizable resources of water and a large cultivable land with a large and growing population to feed. Erratic distribution of rainfall in time and space leads to conditions of floods and droughts which may sometimes occur in the same region in the same year. India has about 16 per cent of the world population as compared to only $4 \%$ of average annual runoff in the rivers. Though, the average annual surface water flows in India has been estimated as 186.9 M.ha-m of which only 69 M.ha-m. can be utilized if appropriate storages can be created.

The reason for this vast difference between potential and the conditional availability has 
been well recognized as the monsoonic climate, besides topographical and geological limitations. In addition to surface water, there is a dynamic (rechargeable) ground water resource. Its potential has been estimated as 43.2 M.ha-m., including recharge due to canal irrigation. This means that the total water availability would be 230.1 M.ha-m. in 2050 or the per-capita availability of $1403 \mathrm{~m}^{3}$. The country will thus be water stressed even if the total available water is taken into account.

On the other side the 1640 million population of India in 2050, half of them urban and half of them rural, would need 9 M.ha.m. of water to meet their domestic needs based on conservative estimates of 200 litre per capita per day (lpcd) for urban areas and 100 lpcd for rural areas. The latter includes demands of live stock. By 2050, India would be a major industrial power in the world. It is estimated that 6.4 M.ha.m. of water will be needed by 2050 to sustain the industries. The country has to increase the area under irrigation. The possible options available to meet the future irrigation and food needs now require a strategy for optimum and sustainable water utilization which should include effective management, proper ground water development, change of cropping pattern according to water availability, evaporation control and reduction of conveyance losses, problems of salinity, alkalinity, water logging etc. The National Water Policy of India (2002) recommends the water resource planning for a hydrological unit on basin basis. River basin based planning and management is found appropriate world- wide in order to have a comprehensive scenario. Looking to these facts a strategy for water resource in upper Narmada Basin is prepared.

\section{Study area}

This study was conducted in upper Narmada basin, a part of Narmada basin in Madhya
Pradesh, India. The Narmada is a major river of the country having basin area of $86256 \mathrm{sq}$ $\mathrm{km}$. This basin is divided into three sub basins namely Narmada upper sub basin, Narmada Middle and Narmada lower as shown in Figure 1. The upper Narmada sub basin comprises of 79 watersheds in $48526 \mathrm{sq} \mathrm{km}$ spread over five revenue districts namely Dindori, Mandla, Jabalpur, Narsinghpur and Hoshangabad.

\section{Materials and Methods}

Estimation of ground water development for all thirty six blocks of Upper Narmada basin has been achieved by finding out the values of ground water recharge, which was used for assessing net availability, as per the norms given by ground water estimation committee (GEC), the existing ground water draft, future reserve for domestic use for Command and Non-command areas separately for all the blocks. The area marked as comfortable zone is covered in Dindori, Mandla, Jabalpur and Hoshangabad districts. Dindori and Mandla are in the hard rock area and having ground water development 2-35\%. Jabalpur is mixed and having ground water development $40 \%$, while Hoshangabad is irrigated through the canals of Tawa project and ground water development is $5-14 \%$ in command area and 18 to $63 \%$ in non-command area.

The units of assessment are categorized into safe, semi critical, critical and overexploited based on the stage of ground water development and the long term trend of pre and post monsoon ground water levels as per C.G.W.B. norms. The gross yearly ground water extraction for irrigation was considered instead of net ground water draft. The gross ground water draft includes the ground water extraction from all the existing ground water structures during monsoon as well as during non-monsoon period. For computing the ground water draft, the norms given by $\mathrm{G} \mathrm{E} \mathrm{C}$ 
(1997) were used for the annual draft from different types of ground water structures. The utilizable ground water potential was assessed as $70 \%$ of difference of available around water potential and present ground water development.

\section{Results and Discussion}

\section{Stage of ground water development}

\section{Dindori district}

It is clear from the table 1 that in Dindori district the ground water development varies from 5 to $16 \%$. Two blocks Amarpur and Mhadwani have even lower ground water development i.e. 5\% and $9 \%$ respectively. These blocks have dense forest and scattered habitation. Karanjia and Dindori are in little better position (11\%) while Samnapur, Shahpura and Bajag have $16 \%$ development.

This poor ground water development may be due to underlain hard rock area. On the other hand the district is exclusively tribal district farmers have less exposure to the technology. Large diameter shallow depth open wells are suitable for such areas in order to utilize temporary storage during rainy season. Intermittent pumping in low yield wells can be practiced to harness the poor yielding aquifer.

\section{Mandla district}

In the tribal district Mandla, the range of ground water development is 2 to 35 percent. Though Mandla is also underlined by hard rock but in valley portions of Narmada and bichhiya, Banjar rivers few pockets are exiting which results in good development of ground water development in Nainpur, Mandla and Bichhiya blocks. Ghughari, Mawai and Bijadandi blocks are having dense forest and hills, serve as recharge zone. Due to poverty, unawareness and migrating tendency of tribes proper development of ground water and development of agriculture could not take place. This entire district falls in underutilized category and there is a lot of scope of ground water development through large diameter shallow open wells and shallow tube wells (Table 2).

\section{Jabalpur district}

Jabalpur district is having a mixed scenario of ground water development. Blocks like Kundam is having $13 \%$ ground water development, while, non-command area of Shahpura block is reaching to $100 \%$ (99\%).Two blocks Panagar and Patan are also having a good development of $67 \%$ and $58 \%$ respectively. Majholi, Sihora and Bargi blocks are still under-utilized. The reason for less ground water utilization may be due to presence canals of RABS Project and a good amount of minor irrigation network commanding 22293 ha.

\section{Narsinghpur district}

In Narsinghpur district ground water development ranges from $57 \%$ to $95 \%$. Two blocks are categorized as critical namely Gotegaon (91\%) and Narsinnghpur (95\%). One block Kareli is in semi critical (73\%) condition. Chichli block is about to cross the safe limit of $70 \%$ by reaching at $69 \%$. Remaining two blocks namely Saikheda and Chawarpatha are also in the race. This situation has brought this district in stress zone as shown in Figure 2. In Narsinghpur district technology of drilling shallow tube wells is easily available in villages also. This has been reported that in villages, local artesian are drilling tube wells, installing pump sets and providing repairing also. Anonymous (2005) reported in a survey conducted by GWU Project, Jabalpur Centre that even about 40 to $50 \%$ farmers are skilled in this job and they make their tube wells themselves. At the same 
time credit facility is available in the local market for casing-pipe and pumpset. This all creates a favorable environment for ground water development. Besides this limited availability of power and its duration forced the farmers to increase number of tube wells even in the same field. Almost the same situation is reported in Shahpura block in Jabalpur district also. These are the facts which brought this area in stress zone. The proposed ground water development for future irrigation should be obtained in a phased manner through construction of different types of ground water recharge structures.

\section{Hosangabad district}

Hoshangabad district is having command area in six out of seven blocks since a long time. Thus, the ground water development is less i.e. $2-17 \%$ in command area and 12 to $63 \%$ in Non-Command area. Bankhedi is the only block having no command area resulting in $63 \%$ ground water development. Based on the aforesaid discussion all the bocks of Upper Narmada Basin are categorized as follows.

\section{Assessment of net availability}

This comparison is made to find out the suitable value of GWR, which may be used for assessing net availability, as per the norms given by GEC, under section 5.6. Then existing ground water draft, future reserve for domestic use are deducted and finally net ground water availability is found out. It is clear from these results that ground water availability is 18661 ha-m in Dindori, 37582 ha-m in Mandla district, 53341 ha-m in Jabalpur district, 31752 ha-m in Narsinghpur district and 172253 ha-m.

\section{Zoning of the study area}

The study area is divided in two zones based on ground water development as shown in Figure 2. First one is stress zone: Area having more than $70 \%$ ground water development and second one is comfortable zone: Area up to $70 \%$ ground water development. Only Narsinghpur district and Shahpura block of Jabalpur district falls under this category as shown in figure 2 by green colour. Rest of the blocks are in comfortable zone and shown by blue colour.

\section{Feasible ground water development}

The number of feasible ground water structures is decided as per the hydrogeological situations given in various reports of Central Ground Water Board, Water Resources Department, Govt. of M.P. and Geological Survey of India and as per the guidelines for annual draft for different types of ground water structures in the states, based on the prevalent practices. Further, the additional area which can be brought under irrigation with these additional wells has also been computed as per the GEC norms. Separate planning for utilizable resource of each district was made as the water source status is varying widely amongst them.

\section{Strategy for water resource utilization}

Water resource is perhaps the only resource, which is being used without any strategy and non-consideration for future demand. Actually, It is not 'used' rather thrown or wasted. Thus, this is the high time to make an effective strategy for water resource utilization and implementation. Two strategies are prepared viz. strategy for stress zone and strategy for comfortable zone and presented here. Further, the strategies are divided in two parts i) Strategy of demand side ii) Strategy of supply side.

\section{Strategy for stress zone}

The area having ground water development of 70 per cent or more is termed as stress zone. This area needs a strategy of monitoring 
ground water development followed by ground water recharge structures.

\section{Strategy for demand side}

Strategy of demand side should be aimed to restrict the demand below the value which needs utilization of $70 \%$ of ground water resource. Thus, the proposed strategy is to use only replenish- able amount of ground water like income and expenditure cycle. To keep ground water level within $70 \%$ in the modified cropping plan is prepared and presented in table 4.

As it is depicted in the table that in existing cropping areas the total water requirement is 97398 ha-m which is higher and putting the area in stress of ground water development. A strategy is planned to reduce this consumption upto 75000 ha-m. On analysis of existing crops-water requirements this fact is found that large area under sugar cane is responsible for this high consumption of water (Table 3 ).

\section{Strategy of supply side}

It needs more emphasis on supply side rather than demand side as there is easy availability of water through tube-wells and canals. Now, the time is alarming to make a strategic use of water, increasing /maintaining the balance handed over by ancestors. In order to achieve this following general strategy is proposed for the stressed areas.

Rainwater harvesting through farm ponds, Nadi, anicuts, percolation tanks, surface check dams, underground check dams, and minor and major surface reservoirs.

Recharging the ground water e.g. recharge through dead wells, nala bunding and anicuts are found to be very suitable for recharging ground water. However, by proper location of rain harvesting structures the ground water recharge can be enhanced without extra cost. Favourable geological features like porous formations, fractures, faults and contact zones between two block types are potentially very good locations where the recharge can take place.

Such sites can be easily identified with help of satellite imageries. These are more significant for recharge of drinking water sources as it increases the dependability.

Conservation of stored water in reservoirs and also in small water harvesting structures, reduction of evaporation losses is important in these for saving water. This loss is proportionate to the water spread.

Normally with full reservoir the total loss in a year would be of the order of 20 per cent whereas when the reservoir is low, the loss would be as high as 75 per cent. Since water is more precious in years when the drought occasion's replenishments are less, special measures need to be considered.

Increasing water use efficiency through micro irrigation systems saving in water is possible if techniques like sprinkler and drip are adopted. By drip saving in water use can be of the order of 40-50 per cent and by sprinkler 8.3-34.7 per cent and gave higher yields. If pressurized irrigation is not feasible then to begin with all flood irrigation should be converted in borders and furrows

It is necessary that by proper legislative measures ground water exploitation is checked and withdrawal is excess of the annual recharge should not be permitted.

Reserve static ground water and water in reservoirs for meeting domestic needs. The ground water forms a significant portion of the total water resources. 
Table.1 Stage of development of ground water development in upper Narmada basin

\begin{tabular}{|c|c|c|c|c|c|}
\hline \multirow[t]{2}{*}{ District } & \multirow[t]{2}{*}{ Block } & \multicolumn{2}{|c|}{$\begin{array}{l}\text { Stage of ground water } \\
\text { Development, } \%\end{array}$} & \multicolumn{2}{|c|}{$\begin{array}{l}\text { Category of ground } \\
\text { water development }\end{array}$} \\
\hline & & Command & $\begin{array}{l}\text { Non } \\
\text { command }\end{array}$ & $\begin{array}{l}\text { Comm } \\
\text { and }\end{array}$ & $\begin{array}{l}\text { Non } \\
\text { command }\end{array}$ \\
\hline \multirow[t]{7}{*}{ Dindori } & Ama rpur & 0 & 9 & Safe & Safe \\
\hline & Baljag & 0 & 15 & Safe & Safe \\
\hline & Dindori & 0 & 11 & Safe & Safe \\
\hline & Karangia & 0 & 11 & Safe & Safe \\
\hline & Mahdwani & 0 & 5 & Safe & Safe \\
\hline & Shahpura & 0 & 15 & Safe & Safe \\
\hline & Samnapur & 0 & 16 & Safe & Safe \\
\hline \multirow[t]{7}{*}{ Hoshangabad } & Bankhedi & 0 & 63 & Safe & Safe \\
\hline & Pipariya & 2 & 31 & Safe & Safe \\
\hline & Sohagpur & 13 & 30 & Safe & Safe \\
\hline & Babai & 17 & 0 & Safe & Safe \\
\hline & Hoshangabad & 9 & 0 & Safe & Safe \\
\hline & Kesla & 2 & 12 & Safe & Safe \\
\hline & Seoni Malwa & 2 & 21 & Safe & Safe \\
\hline \multirow[t]{7}{*}{ Jabalpur } & Bargi & 9 & 45 & Safe & Safe \\
\hline & Kundam & 0 & 13 & Safe & Safe \\
\hline & Sihora & 6 & 30 & Safe & Safe \\
\hline & Panagar & 46 & 67 & Safe & Safe \\
\hline & Majholi & 0 & 29 & Safe & Safe \\
\hline & Shahpura & 55 & 99 & Safe & Critical \\
\hline & Patan & 13 & 58 & Safe & Safe \\
\hline \multirow[t]{9}{*}{ Mandla } & Bijadanndi & 0 & 2 & Safe & Safe \\
\hline & Bichhiya & 2 & 15 & Safe & Safe \\
\hline & Ghughri & 0 & 3 & Safe & Safe \\
\hline & Mandla & 5 & 35 & Safe & Safe \\
\hline & Mohgaon & 0 & 14 & Safe & Safe \\
\hline & Mawai & 0 & 5 & Safe & Safe \\
\hline & Niwas & 0 & 10 & Safe & Safe \\
\hline & Narayanganj & 0 & 10 & Safe & Safe \\
\hline & Nainpur & 5 & 33 & Safe & Safe \\
\hline \multirow[t]{6}{*}{ Narsinghpur } & Kareli & 0 & 73 & Safe & Semi Critical \\
\hline & Chanwarpatha & 0 & 61 & Safe & Safe \\
\hline & Gotegaon & 57 & 91 & Safe & Critical \\
\hline & Narsinghpur & 0 & 95 & Safe & Critical \\
\hline & Chichli & 0 & 69 & Safe & Safe \\
\hline & Saikheda & 0 & 59 & Safe & Safe \\
\hline
\end{tabular}


Table.2 Categorization of ground water utilization in 36 blocks of upper Narmada basin

\begin{tabular}{|l|c|c|c|}
\hline Category & Criterion & $\begin{array}{c}\text { Number of } \\
\text { blocks }\end{array}$ & $\begin{array}{c}\text { Percentage of } \\
\text { study area }\end{array}$ \\
\hline Under Utilized & Below $50 \%$ & 25 & 70 \\
\hline Safe & $50 \%$ to $70 \%$ & 7 & 20 \\
\hline Semi Critical & $70 \%$ to $85 \%$ & 1 & 2 \\
\hline Critical & $85 \%$ to $100 \%$ & 3 & 8 \\
\hline & Total & 36 & 100 \\
\hline
\end{tabular}

Table.3 Modification in demand through crop area adjustment in stress area

\begin{tabular}{|c|c|c|c|c|c|c|c|}
\hline Crop > & Wheat & Gram & S cane & Mustard & Pea & Rabi Area & Total WR \\
\hline \multicolumn{8}{|c|}{ Existing area under crops } \\
\hline Area, ha & 53073 & 136802 & 32415 & 814 & 15600 & 238704 & \\
\hline $\mathrm{IR}, \mathrm{m}$ & 0.35 & 0.25 & 1.25 & 0.25 & 0.25 & & \\
\hline WR, ha-m & 18575.55 & 34200.5 & 40518.75 & 203.5 & 3900 & & 97398.3 \\
\hline \multicolumn{8}{|c|}{ Plan Phase I } \\
\hline Area,ha & 53073 & 136802 & 26915 & 814 & 21100 & 238704 & \\
\hline WR,ha-m & 18575.55 & 34200.5 & 33643.75 & 203.5 & 5275 & & 91898.3 \\
\hline \multicolumn{8}{|c|}{ Plan Phase II } \\
\hline Area,ha & 53073 & 136802 & 21415 & 814 & 26600 & 238704 & \\
\hline WR,ha-m & 18575.55 & 34200.5 & 26768.75 & 203.5 & 6650 & & 86398.3 \\
\hline \multicolumn{8}{|c|}{ Plan Phase III } \\
\hline Area,ha & 53073 & 136802 & 15915 & 814 & 32100 & 238704 & \\
\hline WR,ha-m & 18575.55 & 34200.5 & 19893.75 & 203.5 & 8025 & & 80898.3 \\
\hline \multicolumn{8}{|c|}{ Plan Phase IV } \\
\hline Area,ha & 53073 & 136802 & 10000 & 829 & 38000 & 238704 & \\
\hline WR, ha-m & 18575.55 & 34200.5 & 12500 & 207.25 & 9500 & & 74983.3 \\
\hline
\end{tabular}

Table.4 Number of additional ground water structures to be made in Dindori district

\begin{tabular}{|c|c|c|c|c|c|c|c|}
\hline \multirow[t]{2}{*}{$\begin{array}{l}\text { Name of } \\
\text { Block }\end{array}$} & \multirow{2}{*}{$\begin{array}{l}\text { Net } \\
\text { Sown } \\
\text { Area } \\
\text { (NSA) }\end{array}$} & \multirow{2}{*}{$\begin{array}{l}\text { Existing } \\
\text { G.W. } \\
\text { draft } \\
\text { ha m }\end{array}$} & \multirow{2}{*}{$\begin{array}{l}\text { Utilizable } \\
\text { G.W. } \\
\text { draft } \\
\text { ha m }\end{array}$} & \multicolumn{2}{|c|}{$\begin{array}{c}\text { Feasible No. of } \\
\text { G.W. } \\
\text { Structures }\end{array}$} & \multicolumn{2}{|c|}{$\begin{array}{l}\text { Additional area can be } \\
\text { brought under } \\
\text { irrigation through } \mathrm{OW}\end{array}$} \\
\hline & & & & O.W. & T.W. & Area (ha) & $\begin{array}{c}\text { Percentage } \\
\text { to NSA }\end{array}$ \\
\hline Dindori & 58108 & 312 & 3461 & 2308 & Nil & 4615 & 8 \\
\hline Amarpur & 27780 & 160 & 2474 & 1649 & Nil & 3299 & 12 \\
\hline Samnapur & 30223 & 216 & 1682 & 1121 & Nil & 2243 & 7 \\
\hline Bajag & 32337 & 189 & 2000 & 1333 & Nil & 2666 & 8 \\
\hline Karanjia & 39047 & 297 & 3134 & 2089 & Nil & 4179 & 11 \\
\hline Shahpura & 53883 & 190 & 2296 & 1531 & Nil & 3062 & 6 \\
\hline Mehandwani & 30430 & 1609 & 1020 & 680 & Nil & 1360 & 4 \\
\hline
\end{tabular}


Table.5 Number of additional ground water structures to be made in Mandla district

\begin{tabular}{|c|c|c|c|c|c|c|c|c|c|}
\hline \multirow[t]{3}{*}{$\begin{array}{l}\text { Name of } \\
\text { Block }\end{array}$} & \multirow[t]{3}{*}{$\begin{array}{l}\text { Net } \\
\text { Sown } \\
\text { Area } \\
\text { (ha) }\end{array}$} & \multirow[t]{3}{*}{$\begin{array}{l}\text { Existing } \\
\text { G.W. } \\
\text { Draft } \\
\text { (ha-m) }\end{array}$} & \multirow[t]{3}{*}{$\begin{array}{l}\text { Utilizable } \\
\text { G.W.R. } \\
\text { (ha-m) }\end{array}$} & \multicolumn{2}{|c|}{$\begin{array}{c}\text { Feasible } \\
\text { No. of } \\
\text { G.W. } \\
\text { Structures }\end{array}$} & \multirow{2}{*}{\multicolumn{2}{|c|}{$\begin{array}{c}\text { Additional } \\
\text { Area Can } \\
\text { be Brought } \\
\text { Under } \\
\text { Irrigation } \\
\text { Area (ha) }\end{array}$}} & \multirow{2}{*}{\multicolumn{2}{|c|}{$\begin{array}{c}\text { Percentage } \\
\text { to NSA }\end{array}$}} \\
\hline & & & & \multirow[t]{2}{*}{ OW } & \multirow[t]{2}{*}{ T.W. } & & & & \\
\hline & & & & & & OW & TW & OW & TW \\
\hline Nainpur & 34079 & 1192 & 4320.138 & 2800 & 373 & 5600 & 1493 & 16 & 4 \\
\hline Mandla & 26835 & 1180 & 4151.432 & 2067 & 350 & 4133 & 1401 & 15 & 5 \\
\hline Mongaon & 16854 & 987 & 1046 & 697 & 0 & 1395 & 0 & 8 & 0 \\
\hline Ghughri & 26930 & 39 & 5265 & 3510 & 0 & 7020 & 0 & 26 & 0 \\
\hline Bichhiya & 30403 & 727 & 7390 & 4667 & 463 & 9333 & 1853 & 31 & 6 \\
\hline Mawai & 25442 & 271 & 6746 & 4497 & 0 & 8995 & 0 & 35 & 0 \\
\hline Niwas & 20705 & 175 & 2208 & 1472 & 0 & 2944 & 0 & 14 & $\overline{0}$ \\
\hline Bijadandi & 16395 & 57 & 5763 & 3842 & 0 & 7684 & 0 & 47 & 0 \\
\hline Narayanganj & 16674 & 213 & 2457 & 1638 & 0 & 3276 & 0 & 20 & 0 \\
\hline
\end{tabular}

Table.6 Number of additional ground water structures to be made in Jabalpur district

\begin{tabular}{|c|c|c|c|c|c|c|c|c|}
\hline \multirow[t]{2}{*}{$\begin{array}{c}\text { Name of } \\
\text { Block }\end{array}$} & \multirow{2}{*}{$\begin{array}{l}\text { Com } \\
\text { mand } \\
\text { /Non } \\
\text { com } \\
\text { mand }\end{array}$} & \multirow[t]{2}{*}{ Area } & \multirow[t]{2}{*}{$\begin{array}{l}\text { Existing } \\
\text { G.W.Draft } \\
\text { (ha-m) }\end{array}$} & \multirow[t]{2}{*}{$\begin{array}{c}\text { Utilizable } \\
\text { GW } \\
\text { draft } \\
\text { (ha-m) }\end{array}$} & \multicolumn{2}{|c|}{$\begin{array}{c}\text { Feasible No. } \\
\text { of G.W. } \\
\text { Structures }\end{array}$} & \multicolumn{2}{|c|}{$\begin{array}{c}\text { Additional area } \\
\text { can be brought } \\
\text { under } \\
\text { irrigation }\end{array}$} \\
\hline & & & & & O.W. & T.W. & O.W. & T.W. \\
\hline \multirow[t]{2}{*}{ Jabalpur } & $\mathrm{C}$ & 3640 & 96 & 894 & -- & 298 & - & 894 \\
\hline & $\mathrm{NC}$ & 51310 & 3614 & 2992 & 1995 & - & - & - \\
\hline \multirow[t]{2}{*}{ Majholi } & $\mathrm{C}$ & 0 & 0 & 0 & -- & - & - & - \\
\hline & $\mathrm{NC}$ & 62265 & 3222 & 5453 & 3635 & - & 254 & - \\
\hline \multirow[t]{2}{*}{ Shahpura } & $\mathrm{C}$ & 17834 & 315 & - & -- & 0 & - & - \\
\hline & $\mathrm{NC}$ & 29185 & 10106 & $\mathrm{OE}$ & -- & 100 & - & - \\
\hline \multirow[t]{2}{*}{ Sehor } & $\mathrm{C}$ & 5264 & 134 & 1669 & 877 & 123 & 520 & 910 \\
\hline & $\mathrm{NC}$ & 41120 & 3025 & 4689 & -- & 1563 & - & 840 \\
\hline \multirow[t]{2}{*}{ Panagar } & $\mathrm{C}$ & 3452 & 234 & 308 & -- & 103 & - & 945 \\
\hline & $\mathrm{NC}$ & 46108 & 5208 & 921 & -- & 307 & - & 3787 \\
\hline \multirow[t]{2}{*}{ Kundam } & $\mathrm{C}$ & 0 & 0 & 0 & -- & - & - & - \\
\hline & $\mathrm{NC}$ & 92438 & 715 & 6816 & 4000 & 272 & 1589 & 860 \\
\hline \multirow[t]{2}{*}{ Patan } & $\mathrm{C}$ & 29902 & 245 & $\mathrm{OE}$ & -- & - & - & 10264 \\
\hline & $\mathrm{NC}$ & 70498 & 11938 & $\mathrm{OE}$ & -- & - & - & 752 \\
\hline
\end{tabular}


Table.7 Number of additional ground water structures to be made in Hoshangabad district

\begin{tabular}{|c|c|c|c|c|c|c|c|c|}
\hline \multirow[t]{2}{*}{$\begin{array}{c}\text { Name of } \\
\text { Block }\end{array}$} & \multirow[t]{2}{*}{$\begin{array}{c}\text { Com } \\
\text { mand } \\
\text { /Non com } \\
\text { mand }\end{array}$} & \multirow[t]{2}{*}{$\begin{array}{l}\text { Area } \\
\text { (ha) }\end{array}$} & \multirow[t]{2}{*}{$\begin{array}{c}\text { Existing } \\
\text { GW Draft } \\
\text { (ha-m) }\end{array}$} & \multirow[t]{2}{*}{$\begin{array}{l}\text { Utilizabl } \\
\text { water } \\
\text { (ha-m) }\end{array}$} & \multicolumn{2}{|c|}{$\begin{array}{c}\text { Feasible No. of } \\
\text { G.W. } \\
\text { Structures }\end{array}$} & \multicolumn{2}{|c|}{$\begin{array}{c}\text { Additional } \\
\text { area can be } \\
\text { brought under } \\
\text { irrigation }\end{array}$} \\
\hline & & & & & OW & TW & OW & TW \\
\hline \multirow[t]{2}{*}{ Bankhedi } & $\mathrm{C}$ & 00 & 00 & 00 & 00 & 00 & 00 & 00 \\
\hline & $\mathrm{NC}$ & 82810 & 5478 & 7399 & 637 & 318 & 1274 & 1590 \\
\hline \multirow[t]{2}{*}{ Pipariya } & $\mathrm{C}$ & 11377 & 125 & 10145 & 0 & 3382 & - & 16610 \\
\hline & $\mathrm{NC}$ & 116487 & 4484 & 13493 & 10281 & 3212 & 20562 & 16060 \\
\hline \multirow[t]{2}{*}{ Sohagpur } & $\mathrm{C}$ & 15373 & 1245 & 6987 & 1266 & 1652 & - & 7760 \\
\hline & $\mathrm{NC}$ & 44527 & 2749 & 3943 & 0 & 1314 & - & 6570 \\
\hline \multirow[t]{2}{*}{ Babai } & $\mathrm{C}$ & 59729 & 3496 & 12722 & 0 & 4241 & - & 21205 \\
\hline & $\mathrm{NC}$ & 00 & 0 & 0 & 0 & 0 & - & - \\
\hline \multirow[t]{2}{*}{ Hoshangabad } & $\mathrm{C}$ & 52960 & 2712 & 20564 & 0 & 6855 & - & 34275 \\
\hline & $\mathrm{NC}$ & 00 & 0 & 0 & 0 & 0 & - & - \\
\hline \multirow[t]{2}{*}{ Kesla } & $\mathrm{C}$ & 6570 & 82 & 5196 & 0 & 1732 & - & 8660 \\
\hline & $\mathrm{NC}$ & 76210 & 2841 & 14165 & 2776 & 3333 & 5552 & 16665 \\
\hline \multirow[t]{2}{*}{ Seoni Malwa } & $\mathrm{C}$ & 58080 & 346 & 24708 & 0 & 8236 & - & 41180 \\
\hline & NC & 76887 & 3233 & 8185 & 820 & 2318 & 1640 & 4590 \\
\hline
\end{tabular}

Fig.1 Narmada basin with its sub basins

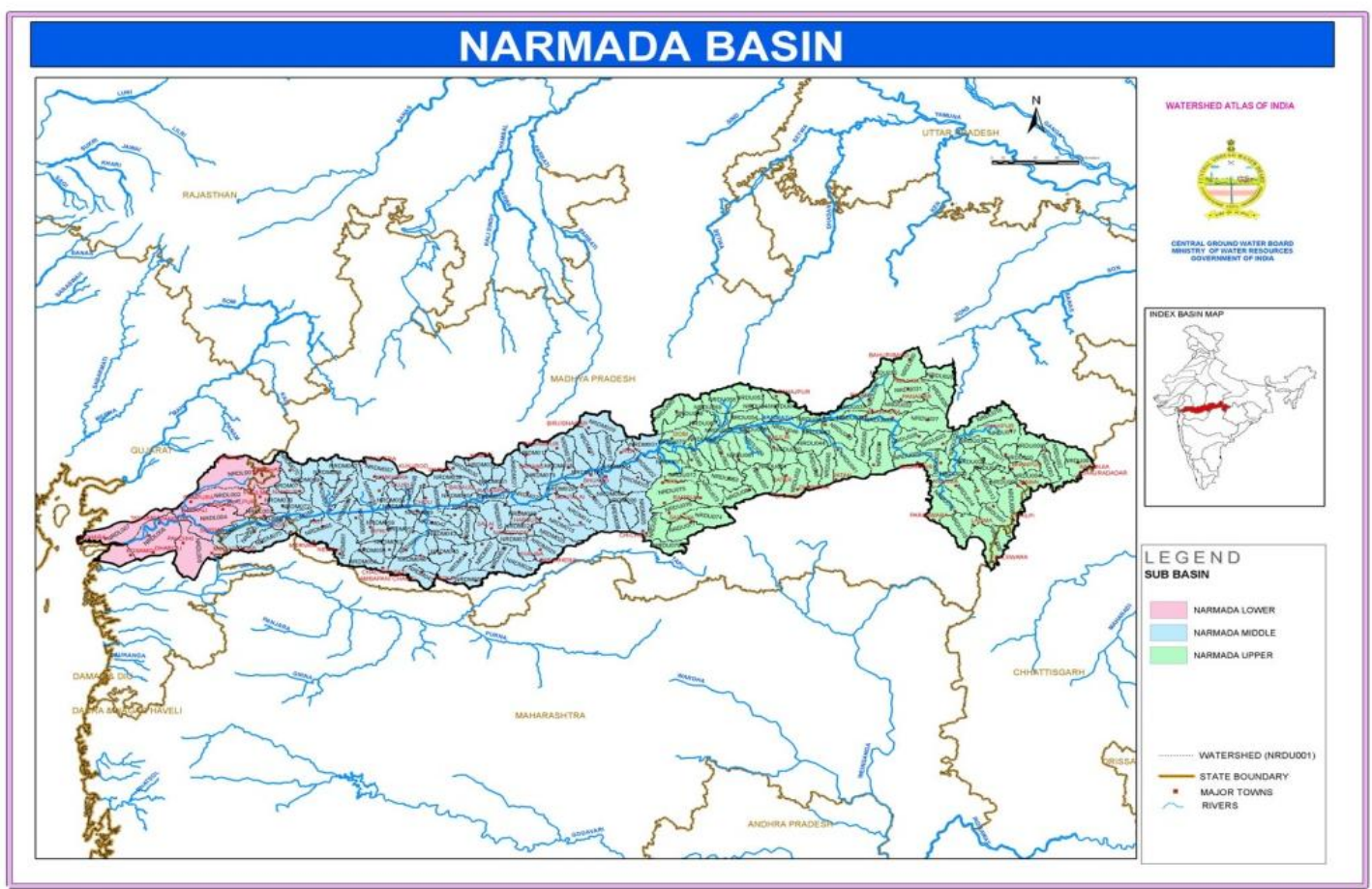


Fig.2 Classification of upper Narmada zone on the basis of ground water development

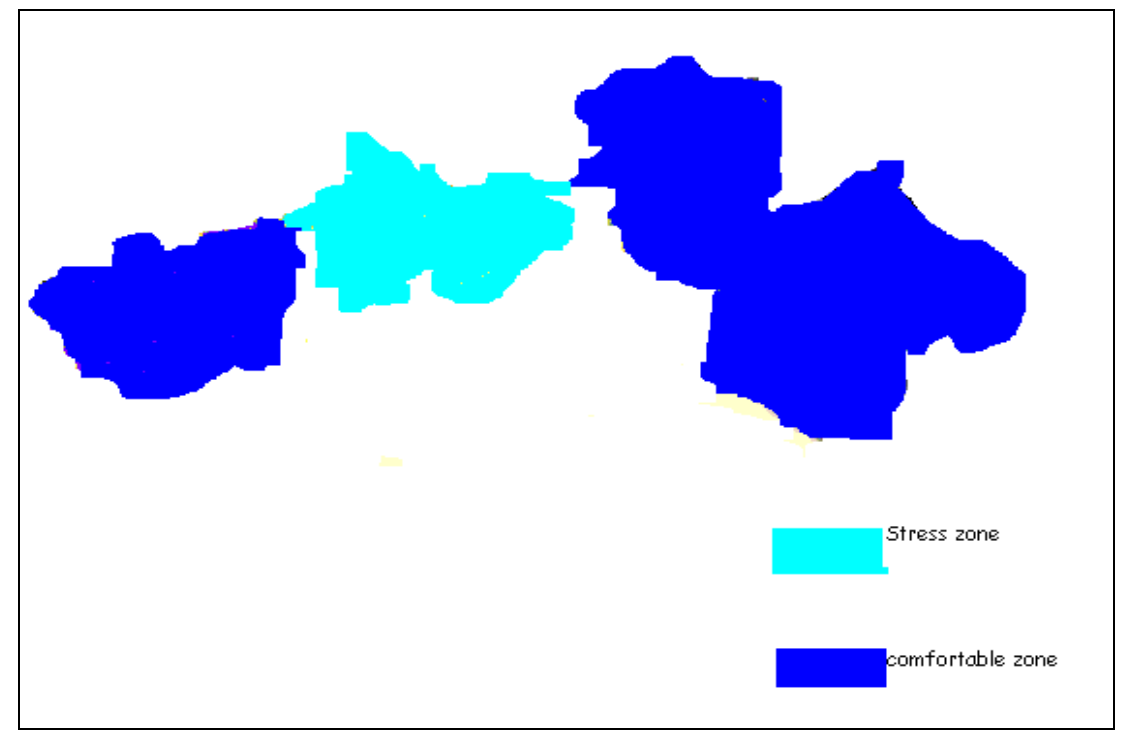

Based on the water table data available, areas have been identified in which declining trend of more than or equal to $0.1 \mathrm{~m} / \mathrm{yr}$ has been recorded in Narsinghpur district. Besides this, geology of area was considered to find out suitable sites for artificial recharge. In this context it was found that southern part of the district is occupied by Basaltic lava flows.

This area is forested and as per the recommendations of CGWB 2002 suitable for construction of percolation tanks. Similarly in the area, north of river Narmada and west of Shakkar River, artificial recharge structure are needed as Phreatic aquifer in this area is desaturated. Watersheds of Sitareva River, Umar river and Dagasia nala provides sufficient surface water for artificial recharge as well as formations are also favorable. A series of nala - bunds and percolation tank is proposed here to provide definite recharge. Sher watershed is another area found suitable for artificial recharge in the south eastern part of the district, where sufficient surface water is available. It is proposed that construction of these structures should be completed in a span of ten years, taking 10 per cent every year, so that increasing demand can be balanced.
Three blocks in Narsingpur disrtrict namely Chichli, Saikheda and Chawarpatha, are in safe category of ground water development. The strategy for further development is to be prepared keeping in view the replenishible recharge in these blocks.

\section{Strategy for comfortable zone}

The area shown by blue colour in Figure 2 is in comfortable position from ground water development point of view.

This area covers almost four districts namely Dindori, Mandla, Jabalpur and Hoshangabad. Both side strategy is prepared for the zone as demand and supply run together.

\section{Strategy for demand side}

The demand side strategy of this zone is to increase the demand means to bring more area under irrigation and to have high remunerative crops.

In order to achieve this, a detailed planning is prepared for all four districts and presented through following tables 5 to 10 . 
Now, the additional area which can be brought under irrigation through these structures is also worked out on the basis of norms as well as reports available. A crop plan has been developed for all the districts of comfortable zone on the basis of utilizable ground water and surface water available. Modified cropping pattern in these districts is as follows

\section{Dindori district}

Mustard area should be increased in the entire districts.

The bunded fields of paddy should be increased.

Early maturing hybrids of paddy should be introduced.

Kodo-kutki + arhar intercropping should be introduced.

Intercropping of gram + mustard should be introduced.

\section{Mandla district}

There should be increase in mustard area in all the blocks, vegetable and fruits in Nainpur, Bichhiya and Mandla Blocks.

The bunded fields of paddy should be increased.

Early maturing hybrids of paddy should be introduced.

Lac cultivation should 1 be introduced in larger area.

\section{Jabalpur district}

There should be increase in sugarcane area in Shahpura, Patan and Panagar blocks.
Introduction of hybrid and scented rice in Shahpura, Patan, Sihora and Panagar blocks should be made.

Green-pea area should be increased in command area followed by short duration varieties of wheat.

\section{Hoshangabad district}

Hybrid and scented rice should be encouraged.

Soybean area should be reduced and Urad followed by vegetable Pea followed by late Wheat may be tried as an alternate.

The present paddy area should be increased by 10000 ha and this may be drawn from soybean area under water logging area.

Wheat area should be remained the same.

Sugarcane area should be increased.

Summer moong should be introduced in 2000 ha area.

Sericulture should be promoted.

Fruit and vegetable area should be increased.

Increase pea area.

\section{Strategy for supply side}

Use efficient irrigation methods.

Conjunctive use of surface and ground water should be adopted in ratio of 60:40 immediately in the command area of Jabalpur as well as Hoshangabad districts.

Controlling of pollution of Narmada and its tributaries through industrial effluents, as also effluents from the domestic sewage, which is being drained directly. This needs to be properly treated before discharged into 
streams.

Based on above analysis, following conclusions are obtained.

The net ground water availability is minimum in Dindori district i.e. 25022 ha-m and maximum in Hoshangabad district 128280 ham.

Ground water development varies from $2 \%$ to $105 \%$ in the study area.

In command area, it varies $2-55 \%$ and in noncommand area $2 \%$ in Bijadandi block of Mandla and $105 \%$ in Gotegaon block of Narsinghpur district.

In Dindori district 4-12\% in Mandla district 8$35 \%$ additional area can be brought under irrigation with the proposed ground water development.

In Jabalpur district 5-12\% additional area can be brought under irrigation.

In Narsinghpur district the situation of ground water development is in stress. One block Gotegoan is over exploited and another three blocks Narsinghpur (98\%), Chichli (81\%) and Saikheda $(96 \%)$ are in critical stage.

Other two blocks are at $60 \%$ though in safe category but in near future it may cross the limit i.e. $60 \%$ and $65 \%$.The artificial ground water recharge is needed immediately.

Ground water extraction in Narsinghpur district should be controlled by "law" and a modification in cropping pattern should 1 be followed immediately.

Sugarcane area should be brought at $25 \%$ of present level. This area should be diverted to "pea" cultivation both as "vegetable and grain".

In Hoshangabad, Bankhedi block is in critical condition (94\%) and needs artificial recharge and controlled development of ground water.

Non-command area of Pipariya block is having a rapid development of ground water so artificial recharge structures should be constructed as per the plan developed.

Area of horticulture and sugarcane should be increased in command area of Hoshangabad district.

\section{References}

Anonymous (2002 a) "National Water Policy" Ministry of W.R.G.O.I.New Delhi.

Anonymous (2002 b) Master Plan for Artificial Recharge, C.G.W.B. Ministry of W.R.G.O.I.New Delhi

Anonymous(2008) Annual Progress Report of AICRP on Ground Water Utilization , Jabalpur Centre,JNKVV, Jabalpur

Anonymous (2009) District Statistical Book of Dindori, Mandla,Jabalpur, Narsinghpur and Hoshangabad. Govt of M.P. .

G.E.C. (2009) Report of Ground Water Estimation Committee, C.G.W.B. Ministry of W.R.G.O.I.New Delhi

Nema R.K. (1995) Water Balance Studies for Planning Conjunctive Use- A case Sudy of New Canal Irrigation Project.Ph.D. Thesis,

Division of Agricultural Engineering IARI New Delhi.

Parmar B.J. and Gulati O.T.(2005) Sustainable Water Resource Development through Integrated River Basin Management on

Sabarmati River Basin of India. J of Water Resources.

\section{How to cite this article:}

Shrivastava, R.N., R.K. Nema and Awasthi, M.K. 2018. Strategy of Water Resource Utilization in Upper Narmada Basin. Int.J.Curr.Microbiol.App.Sci. 7(05): 591-602.

doi: https://doi.org/10.20546/ijcmas.2018.705.073 